\begin{tabular}{lc}
\hline CURRENT & ISSN: 0973-4929, Vol. 13, No. (1) 2018, Pg. 15-31 \\
WORLD & Current World Environment
\end{tabular}

ENVIRONMENT

Journal Website: www.cwejournal.org

\title{
Human Health Risk Assessment of Heavy Metals in the Black Sea: Evaluating Mussels
}

\author{
LEVENT BAT $^{1 *}$, ELIF ARICI ${ }^{1}$ and AYSAH ÖZTEKIN ${ }^{2}$ \\ ${ }^{1}$ University of Sinop, Fisheries Faculty, Department of Hydrobiology, Sinop, Turkey. \\ ${ }^{2}$ University of Sinop, Fisheries Faculty, Department of Fisheries Basic Sciences, Sinop, Turkey.
}

\section{Abstract}

The levels of Fe, $\mathrm{Zn}, \mathrm{Mn}, \mathrm{Cu}, \mathrm{Pb}, \mathrm{Cd}$ and $\mathrm{Hg}$ in the edible tissues of Mytilus galloprovincialis Lamarck, 1819 (Mediterranean mussel) picked up from the Black Sea coasts of Turkey have been determined by Inductively Coupled Plasma - Mass Spectrometer (ICP/MS) with a view to biomonitoring metal contamination in 2015. In this work, a statistically significant difference in the amounts of all studied heavy metals analyzed was noticed amidst sampling areas namely Igneada, Sinop, Samsun and Trabzon so that appraise welfare threat for mussel consumers, utilization M. galloprovincialis as biomonitors. The outcomes of this study were contrasted with the outlines stated by the Ministry of Agriculture, Fisheries and Food (MAFF), the Turkish Food Codex and Commission Regulation (EC) for the harmless consumption restrictions of Bivalves as seafood. Moreover, former works with mussels in the Black Sea countries were reviewed and a summary of heavy metal amounts in mussels from whole the Black Sea waters were presented. In general these available measurements clearly indicated a low level heavy metal in M. galloprovincialis in coastal waters of the Black Sea. In this study the concentrations (mg metal kg-1 wet wt.) of metals ranged from 18-35 for Fe, 8-27 for $\mathrm{Zn}, 2.8$ 4.5 for $\mathrm{Mn}, 0.5-1.8$ for $\mathrm{Cu}, 0.06-0.31$ for $\mathrm{Pb}, 0.04-0.10$ for $\mathrm{Cd}$ and 0.03-0.07 for $\mathrm{Hg}$. Considering human health with respect to the investigated heavy metals, the estimated daily intakes (EDIs) did not exceed the permissible intakes. No chronic systemic risk was found since total hazard index $(0.521)$ were quite below critical value 1 , and the carcinogenic risk for heavy metals did not exceed the tolerable values. Although there was no health risk to consumed mussels from the Black Sea riparian countries, the amount of mussels consumed is mainly unknown in countries; thus, consumption of about 1 serving of mussels from clean coastal waters per week is enough.

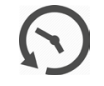

\section{Article History}

Received: 27 November 2017

Accepted: 11 February

2018

\section{Keywords}

\section{Mytilus}

galloprovincialis,

Biomonitoring,

Heavy metal,

Black Sea,

Risk assessment,

Estimated daily intakes,

Total hazard index.

CONTACT Levent Bat leventbat@gmail.com 9 University of Sinop, Fisheries Faculty, Department of Hydrobiology, Sinop, Turkey. (c) 2018 The Author(s). Published by Enviro Research Publishers

This is an 6 Open Access article licensed under a Creative Commons Attribution-NonCommercial-ShareAlike 4.0 International License (https://creativecommons.org/licenses/by-nc-sa/4.0/), which permits unrestricted NonCommercial use, distribution, and reproduction in any medium, provided the original work is properly cited.

To link to this article: http://dx.doi.org/10.12944/CWE.13.1.03 


\section{Introduction}

The Marine Strategy Framework Directive (MSFD) of the European Parliament and of the Council constituted a structure for community movement in the area of marine ecological strategy. It established that European Union (EU) Member States have to define Good Environmental Status (GES), to set environmental target, to develop operative monitoring programmes and to assess every six years the environmental situation of their sea water, by 2020 , using eleven qualitative descriptors . Turkey $_{1}$ has signed this agreement as well. The main goals of the MSFD are to keep safe and to take care of the marine ecosystem and to stop and to reduce inputs from pollutants. The quantity of pollutants with the inclusion of heavy metals in the marine ecosystem and their impacts necessity to be evaluated considering the impacts and threatening to the ecosystem in Article 8(1)(b)(ii) of Directive 2008/56/ EC. Pollutants in biota for people consumption do not pass over amounts based by Community acts or other germane rules (Descriptor 9; Directive $2000 / 60 / E C)^{2}$. The Black Sea is a European sea now because of Bulgaria and Romania joint the European Union.

Due to its geographical position and limited water change with the rest of other oceans and seas in the World, the Black Sea has been one of the unique basins most polluted with the heavy metals. The total volume of the sea is $547.000 \mathrm{~km}^{3}, 87 \%$ of which is covered with oxygen-poor water ${ }^{3}$. Due to the excessive input of freshwater, which causes low salinity in the top waters of the Black Sea, and to the inflow of saline Mediterranean waters into the deep basin, stable salinity stratification has been occurred.In the past three decades, pollution of the Black Sea by pollutants has turn out an important issue ${ }^{4}$. These pollutants transport tremendous amount of chemicals particularly the heavy metals have the propensity to cumulate inside the primary food chain and ascend by courtesy of the high-rise trophic grade and consequence in unfavorable impact on the sea resources thence allow of commercial loss. Heavy metals are perceived as lasting and damaging chemicals of aquatic ecosystem in consequence of their toxicity.It is known that nonessential metals are toxic to alive biota insomuch as at low levels, whilst biologically necessary metals may happen toxic at somewhat high levels ${ }^{5,6}$. For example, mercury is one of the heavy metals of actual concern in pollution works onwards the emanation in Japan of Minamata disease in the 1950s. This disease was a result of eating fish and shrimps polluted by methyl mercury from the wastewaters discharged by chloralkali factories. Regional folks of Minamata, who eaten up extremely on seafood, were at hazard of exposure to methyl mercury led to intense neurological harm and died more than 900 people. Furthermore almost two million people off the region suffered welfare causes ${ }^{7}$. Other instance is the itai itai disease in Fugawa, Japan in 1955. It was the reaction of eating fish and bivalves that were $\mathrm{Cd}$ polluted from waste waters unloaded by close mining ${ }^{8}$. Heavy metals are of environmental concern in the Black Sea due to the presence of populations of edible mussels that are known to accumulate these elements. $M$. galloprovincialisis much effective at changing nominal worth supplies into great standard animal protein ${ }^{9}$. Mussels are used as a food source in the Black Sea countries. It was reported that mussels production in entire Black Sea coast as $4321 \mathrm{t}$ (Turkey: $243 \mathrm{t}$; Bulgaria: 3391 t; Romania: 81 t; Ukraine: 605 t; Russia: 1 t) in $2015.80 .6 \%$ of the total production was occurred aquaculture and $19.4 \%$ of capture ${ }^{10}$.Monitoring of heavy metals in mussels was achieved in the Black Sea for many decades.

The common mussel (Mytilus galloprovincialis L.) is one of the most important Mollusca on the rocky and gravel bottoms of the Black Sea. They have an important role in the recycling of nutrients and particles, using suspended materials from the water column. At the same time mussels accumulate metals in their soft tissue and they are valuable indicators of heavy metal pollution of marine ecosystems ${ }^{9}$. Clearly M. galloprovincialis has potential as bio-monitor species for heavy metal pollution in marine waters. Because this organism is a benthic and sessile and it is incessantly exposed to pollutants. Moreover mussels ingest particles contaminated with heavy metals while feeding, are existing year throughout, oft take place in major densities, one important in food chains, and have a broad geographical range. The purpose of the present work is to investigate the amounts of $\mathrm{Fe}, \mathrm{Zn}, \mathrm{Mn}, \mathrm{Cu}, \mathrm{Pb}, \mathrm{Cd}$ and $\mathrm{Hg}$ in $\mathrm{M}$. galloprovincialis and to check the outcomes of the current work with the utmost allowable levels of these elements recommended by European Union ${ }^{11}$ and 
Turkish Food Codex ${ }^{12,13}$ and to compare the results with those obtained in preceding studies and to assess the potential health risk for consumers in the Black Sea coasts based on their intake. The present study also provides an overview of the studies in the Black Sea riparian countries and assesses recent levels of heavy metal pollution.

\section{Materials and Methods}

The material was collected in 2015 from mussel (M. galloprovincialis) (Figure 1) habitats by the small rocky habitats amid four sampling regions namely Igneada, Sinop, Samsun and Trabzon coast of the Black Sea (Figure 2). There has been increased population density in the coastal cities giving rise to more pollution. The rapid urbanization that has been taking place in coastal area is one of the very significant causes of the Black Sea pollution. Among the developments affecting coastal pollution in the cities, many other factors play major roles. Some of these include domestic wastes, incorrect urbanization, fishing activities, an increase in the number of tourists and inadequate disposal of wastes. In terms of industrialization and urbanization Igneada and Sinop coasts are relatively considered uncontaminated. Areas significantly affected by industrial pollution in the Black Sea coast of Turkey are Samsun and Trabzon. Especially the fertilizer industry is located in Samsun and the cement industry in Trabzon ${ }^{14}$.

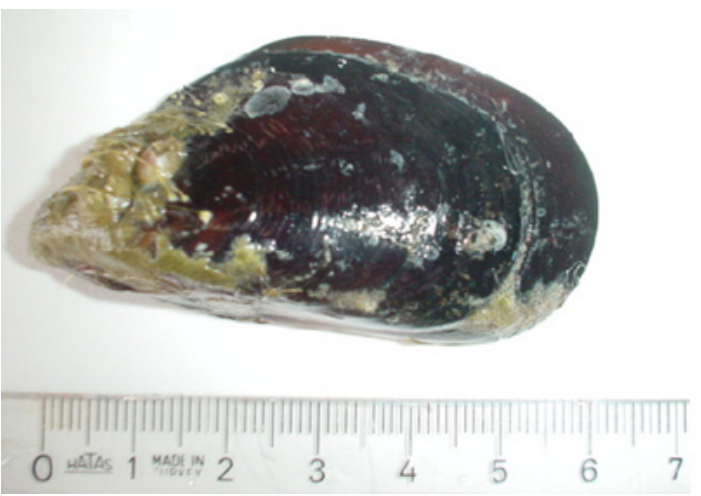

Fig. 1: Mytilus galloprovincialis L.

The bottom usually changes from rock covered by filamentous algae to sand and gravel. Mussel specimens were picked up by SCUBA-diving at a deep space of $10-20 \mathrm{~m}$, wherewith the M. galloprovincialis settlements were intensive.
Samples were carried right away from the stations to the Hydrobiology Laboratory of Fisheries Faculty, Sinop and next they were put apart in clean seawater in aquariums $(20 \times 20 \times 25 \mathrm{~cm})$ for $24 \mathrm{~h}$ to defecate the contents in alimentary canals. After removal of the bowel contents, the samples were separated with respect to their sizes and were allocated into edible tissues. The specimens were put in nylon bags in a deep freeze at $-21^{\circ} \mathrm{C}$ up to their analysis. To acquire three homogeneous samples of each biological sample for analysis, a portion of edible muscle tissue was taken from mussel, and was washed with $\mathrm{HNO}_{3}$ and rinsed with deionized water. The samples digested with Suprapur $\mathrm{HNO}_{3}$ (nitric acid) using a microwave digestion system (Milestone Systems, Start D 260) for analysis. In parallel, blanks and certified reference material samples were processed similarly to verify the accuracy and precision of the method. Heavy metal analysis in mussels was performed by accredited Çevre Food Analysis Laboratory Environmental Industrial Analysis Industry and Trade Inc.Samples were analyzed by an ICP-MS, Agilent Technologies, 7700X and application of m-AOAC 999.10 (AOAC: Association of Official Analytical Chemists; reference number TÜRKAK Test TS EN ISO IEC 17025 AB0364-T) and CSN EN 15763 European Standard methods. It was used for qualitative and quantitative elemental analysis. Advantages of ICP-MS are extremely low detection limits, wide linear range and uncomplicated spectra. The sensitivity of the method was determined according to the detection limits established for the spectrometer, which were $<0.001 \mu \mathrm{g} / \mathrm{L}$ for $\mathrm{Mn}, \mathrm{Fe}, \mathrm{Pb}$ and $\mathrm{Cd},<0.01 \mathrm{Zn}$ and $\mathrm{Hg}$ and $<0.0001 \mu \mathrm{g} / \mathrm{L}$ for $\mathrm{Cu}$.

The operational conditions of ICP-MS set for the analysis of the metals are shown in Table 1.

The accuracy of the analytical method in the current work was assessed using the Standard Reference Material (SRM) 2976 (mussel tissue) from National Institute of Standards and Technology (NIST). Results of the measurements were in good agreement between the certified and the analytical values, together with the Relative Standard Deviation (RSD) percentage which always range of $10 \%$. The certified reference values were $33 \pm 2,171.0 \pm 4.9$, $1.19 \pm 0.18,0.82 \pm 0.16,137 \pm 13,61.0 \pm 3.6$ and $4.02 \pm 0.33 \mathrm{mg} / \mathrm{kg}$ for $\mathrm{Mn}, \mathrm{Fe}, \mathrm{Pb}, \mathrm{Cd}, \mathrm{Zn}, \mathrm{Hg}$ and 
$\mathrm{Cu}$, respectively. The analytical values of the current work were found as $31.1 \pm 1.6 \mathrm{mg} / \mathrm{kg}(95 \%)$ for $\mathrm{Mn}$, $159.6 \pm 3.8 \mathrm{mg} / \mathrm{kg}(0.93 \%)$ for Fe, $1.09 \pm 0.11 \mathrm{mg} / \mathrm{kg}$ $(92 \%)$ for $\mathrm{Pb}, 0.77 \pm 0.13 \mathrm{mg} / \mathrm{kg}(94 \%)$ for $\mathrm{Cd}, 125 \pm$ $9.0 \mathrm{mg} / \mathrm{kg}(0.91 \%)$ for $\mathrm{Zn}, 65.5 \pm 4.3 \mathrm{mg} / \mathrm{kg}(107 \%)$ for $\mathrm{Hg}$ and $3.71 \pm 0.25 \mathrm{mg} / \mathrm{kg}(92 \%)$ for $\mathrm{Cu}$.

All samples were analyzed in triplicate and the results were expressed as $\mathrm{mg} \mathrm{kg}^{-1}$ wet weight.

Table 1: ICP-MS operating conditions for the analysis

\begin{tabular}{ll}
\hline Operating conditions & Value \\
\hline Plasma mode & Normal, robust \\
RF power $(\mathrm{W})$ & 1550 \\
Sampling depth $(\mathrm{mm})$ & 8 \\
Nebulizer $(\mathrm{mL} / \mathrm{min})$ & $\sim 0.2$ \\
Spray chamber temperature $\left({ }^{\circ} \mathrm{C}\right)$ & 2 \\
Carrier gas flow $(\mathrm{L} / \mathrm{min})$ & 0.95 \\
Dilution gas flow $(\mathrm{L} / \mathrm{min})$ & 0.15 \\
Extraction lens $1(\mathrm{~V})$ & 0 \\
Kinetic energy discrimination $(\mathrm{V})$ & 4 \\
Cell gas $(\mathrm{He})$ flow $(\mathrm{mL} / \mathrm{min})$ & 4 \\
Background on-mass $(\mathrm{cps})$ & $<2$ \\
Integration time $(\mu \mathrm{s})$ & 100 \\
\hline
\end{tabular}

Assessments Total Hazard Index (Thi) of Heavy Metals in Mussels

Hazard from metals entering owing to ingestion may be defined using a THI as the rate of the estimated daily intake (EDI) $\mathrm{mg} / \mathrm{kg}$ of body wt. and the reference dose (RfD mg/ kg.). The THI was computed by using the equation below:

$\mathrm{THI}=\mathrm{EDI} / \mathrm{RfD}$

If THI > 1.0, so the EDI of a certain element overruns the $\mathrm{RfD}$, pointing out that there is a possible hazard associated with that element. The EDI depends on both the metal amount and the quantity of consumption of seafood.The EDI of elements was calculated using the equation below:

$\mathrm{EDI}=\mathrm{C}_{\text {metal }} \times \mathrm{W}_{\text {mussel }} / \mathrm{BW}$

Where: $C_{\text {metal }}$ is the metal levels in mussels; $W_{\text {mussel }}$ represents the daily mean consumption of mussels;
Bw is the body weight of an adult $(\mathrm{kg})$. The estimated weekly intakes (EWI) were calculated from EDI.

\section{Results and Discussion}

The concentrations ( $\mathrm{mg}$ metal $\mathrm{kg}^{-1}$ wet wt.) of the elements ranged from 18-35 for Fe, 8-27 for $\mathrm{Zn}$, 2.8-4.5 for $\mathrm{Mn}, 0.5$-1.8 for $\mathrm{Cu}, 0.06-0.31$ for $\mathrm{Pb}, 0.04$ 0.10 for $\mathrm{Cd}$ and $0.03-0.07$ for $\mathrm{Hg}$ (Figure 3). Sinop is small city and contaminants load less than those in both Samsun and Trabzon. Relying on metal levels, Samsun demonstrated the greater levels of $\mathrm{Fe}, \mathrm{Cu}$, $\mathrm{Cd}$ and $\mathrm{Hg}$ whereas $\mathrm{Zn}$ and $\mathrm{Pb}$ levels were higher in Trabzon and $\mathrm{Mn}$ was maximum value in Igneada.

Present study provides the information on the accumulation of elements in the edible parts of mussels from the Turkish Black Sea coasts. In general, the measured heavy metals showed a low tendency to accumulate in the tissues. However, in this study, concentrations of the heavy metals in edible parts of mussels were compared Turkish Food Codex ${ }^{12,13}$, the Commission Regulation ${ }^{11,15}$ and MAFF $^{16}$ standard values (see Table 1). The heavy metal levels in edible part of the mollusks are below the proposed limit values for human consumption.

Considering tolerable limits, outcomes in all studied areas indicate that those who consume mussels in the Black Seaseem to have no health problems. Besides, the Provisional Tolerable Weekly Intake (PTWI) amount is evaluate of the level of a metal that may be taken by people duringtime of life out perceptible risk. PTWI is set up by the Joint Food and Agricultural Organization (FAO) for the United Nations / World Health Organization (WHO) Expert Committee on Food Additives (JECFA).

The mean daily mussels' consumption in Turkey is $1 \mathrm{~g}$ per person ${ }^{17}$. However, this amount is higher in the Black Sea coastal cities of Turkey. Therefore both minimum and maximum values of Estimated Weekly Intakes (EWI) and Estimated Daily Intakes (EDI) for a $70 \mathrm{~kg}$ adult person on basis of the current workoutcomes are calculated and presented in Table 2.

It can be considered from Table 3 that the calculated EWIs and EDIs of heavy metals in the current work are quite down the advised PTWIs and PTDIs and 
remarked no opposed influence to the people. consumption of $M$. galloprovincialis picked up from Hence it could be finalized that there is no danger in the Black Sea shores of Turkey.

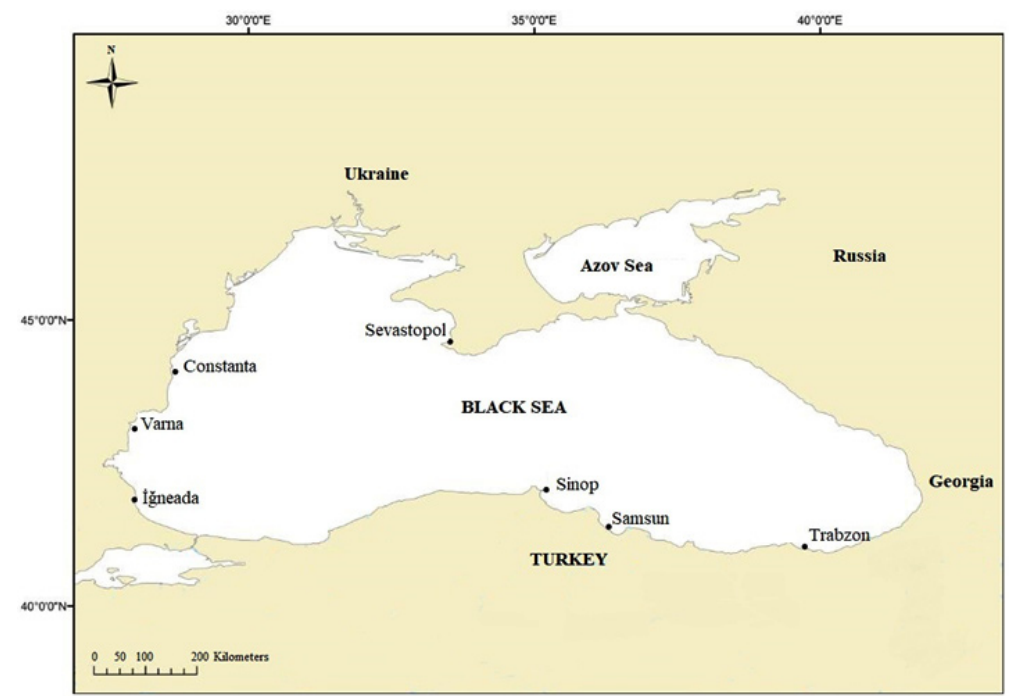

Figure 2: Mussels sampling area from the Turkish Black Sea coasts

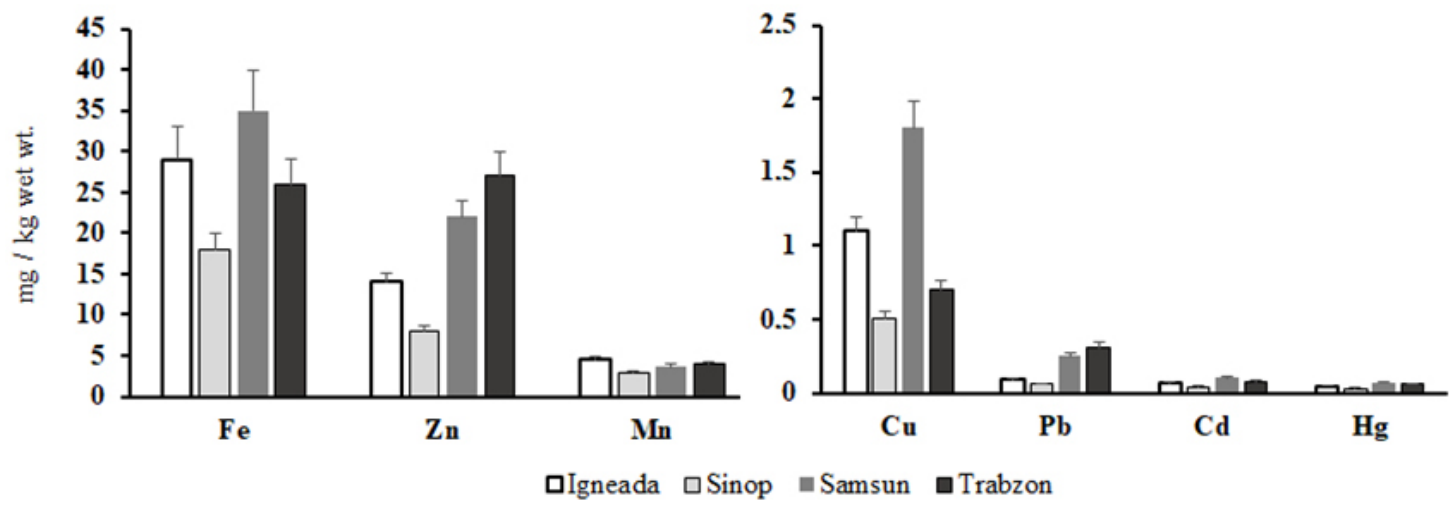

Fig. 3: Mean heavy metal concentrations with standard errors in Mytilus galloprovincialis from the

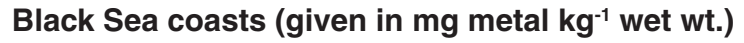

Table 2: The tolerable values of measured metals in Mollusca (mg/kg wet wt.)

\begin{tabular}{llllll}
\hline Standards & $\mathbf{C d}$ & $\mathbf{P b}$ & $\mathbf{C u}$ & $\mathbf{Z n}$ & $\mathbf{H g}$ \\
\hline MAFF, The Food Safety $^{16}$ & $<0.2$ & 10 & 20 & 50 & -- \\
The Commission Regulation $^{15}$ & 1.0 & 1.5 & -- & -- & 0.5 \\
Turkish Food Codex $^{12}$ & 1.0 & 1.5 & 20 & 50 & 0.5 \\
The Commission Regulation $^{11}$ & 1.0 & 1.5 & -- & -- & 0.5 \\
Turkish Food Codex $^{13}$ & 1.0 & 1.5 & -- & -- & 0.5 \\
\hline
\end{tabular}


Table 3: Estimated Weekly Intakes (EWI) and Estimated Daily Intakes (EDI) of heavy metals in M. galloprovincialis from the Turkish Black Sea coasts

\begin{tabular}{|c|c|c|c|c|c|c|c|}
\hline \multirow[t]{2}{*}{ Metals } & \multirow[t]{2}{*}{ PTWla } & \multirow[t]{2}{*}{ PTWlb } & \multirow[t]{2}{*}{ PTDI ${ }^{c}$} & \multicolumn{2}{|c|}{$E W l^{d}$} & \multicolumn{2}{|c|}{ EDIe } \\
\hline & & & & Min. & Max. & Min. & Max. \\
\hline $\mathrm{Fe}$ & 5.6 & 392 & 56 & 0.126 & 0.245 & 0.018 & 0.035 \\
\hline $\mathrm{Zn}$ & 7 & 490 & 70 & 0.056 & 0.189 & 0.008 & 0.027 \\
\hline $\mathrm{Mn}$ & $2-5$ & $140-350$ & $20-50$ & 0.0196 & 0.0315 & 0.0028 & 0.0045 \\
\hline $\mathrm{Cu}$ & 3.5 & 245 & 35 & 0.0035 & 0.0126 & 0.0005 & 0.0018 \\
\hline $\mathrm{Pb}$ & 0.025 & 1.75 & 0.25 & 0.00042 & 0.00217 & 0.00006 & 0.00031 \\
\hline $\mathrm{Cd}$ & 0.007 & 0.49 & 0.07 & 0.00028 & 0.0007 & 0.00004 & 0.0001 \\
\hline $\mathrm{Hq}$ & 0.004 & 0.28 & 0.04 & 0.00021 & 0.00049 & 0.00003 & 0.00007 \\
\hline
\end{tabular}

aPTWI (Provisional Tolerable Weekly Intake) in $\mathrm{mg} / \mathrm{week} / \mathrm{kg}$ body wt.

bPTWI for $70 \mathrm{~kg}$ adult person (mg/week/70 kg body wt.)

cPTDI (Permissible Tolerable Daily Intake) (mg/day/70 kg body wt.)

${ }^{d}$ EWI (Estimated Weekly Intake) (mg/week/ kg body wt.)

${ }^{e}$ EDI (Estimated Daily Intake) (mg/day/ kg body wt.)

Heavy metals are one of the most significant contaminant of the aquatic environmental. Heavy metals are higher in areas close to the shore, especially in industrial areas and where large cities are located. Monitoring of the marine coasts has resulting due to the need to keep safe living organisms and human health through food web. Pollution monitoring studies are utility road for judging the actual situation of coastal environments, for determining tendency in contaminants especially heavy metals over space and time, and for assigning potential sources of contamination to protect coming problems. More than 40 years, Mytilus spp. have been successfully studiedas biomonitors of heavy metal contamination in marine coasts ${ }^{4,18}$, since these bivalves meet most of the required criteria for biomonitor species ${ }^{19,20,21,22}$.

In relation to other coasts of countries in the Black Sea, heavy metal levels in M. galloprovincialis in this current study were compared with other studies (Table 4).Big disparities in heavy metal levels in mussels were seen among different regions.In Russian coasts of the Black Sea Fe, Mn, $\mathrm{Cu}, \mathrm{Pb}, \mathrm{Cr}$, As and Ni values were highest in Blue Bay. $\mathrm{Zn}$ and $\mathrm{Cd}$ values were highest in Inal Bay and $\mathrm{Hg}$ values were observed in Crimean coasts. When the maximum values of the metals are taken into consideration, the order of the metal values obtained in all studies conducted on the Russian coast is; $\mathrm{Fe}>\mathrm{Zn}>\mathrm{Cr}>$ $\mathrm{Cu}>\mathrm{Pb}>\mathrm{Mn}>\mathrm{As}>\mathrm{Cd}>\mathrm{Ni}>\mathrm{Hg}$.

The metal values conducted on the border between Ukraine and Romania were found as $\mathrm{Cu}>\mathrm{Ni}>\mathrm{Cd}>$ $\mathrm{Cr}>\mathrm{Pb}$.

Unfortunately there was not found available literature in Georgian coasts of the Black Sea.

In Romanian the highest values of $\mathrm{Fe}, \mathrm{Mn}, \mathrm{Cu}, \mathrm{Cd}$, $\mathrm{Pb}$ and $\mathrm{Ni}$ were observed on VamaVeche coasts and $\mathrm{Hg}$ value on the highest North Efoire coasts. When the maximum values of all metals are taken into consideration, the order of the metal values in the Romanian coast is as follows: $\mathrm{Fe}>\mathrm{Mn}>\mathrm{Zn}>\mathrm{Cd}>$ $\mathrm{Cu}>\mathrm{Cr}>\mathrm{Pb}>\mathrm{Ni}>\mathrm{Hg}$.

In the highest values of $\mathrm{Fe}, \mathrm{Mn}, \mathrm{Cr}$ and As were found in the coasts of the southwestern Bulgaria of the Black Sea with the highest values of $\mathrm{Zn}$ and $\mathrm{Cd}$, and Gulf of Varna, $\mathrm{Cu}$ and $\mathrm{Pb}$ were highest in Cape Galata coasts. The order of the metal values obtained in the studies carried out on the Bulgarian coast is found as $\mathrm{Zn}>\mathrm{Fe}>\mathrm{Cu}>\mathrm{Mn}>\mathrm{As}>\mathrm{Cd}>\mathrm{Cr}>$ $\mathrm{Ni}>\mathrm{Pb}$. 


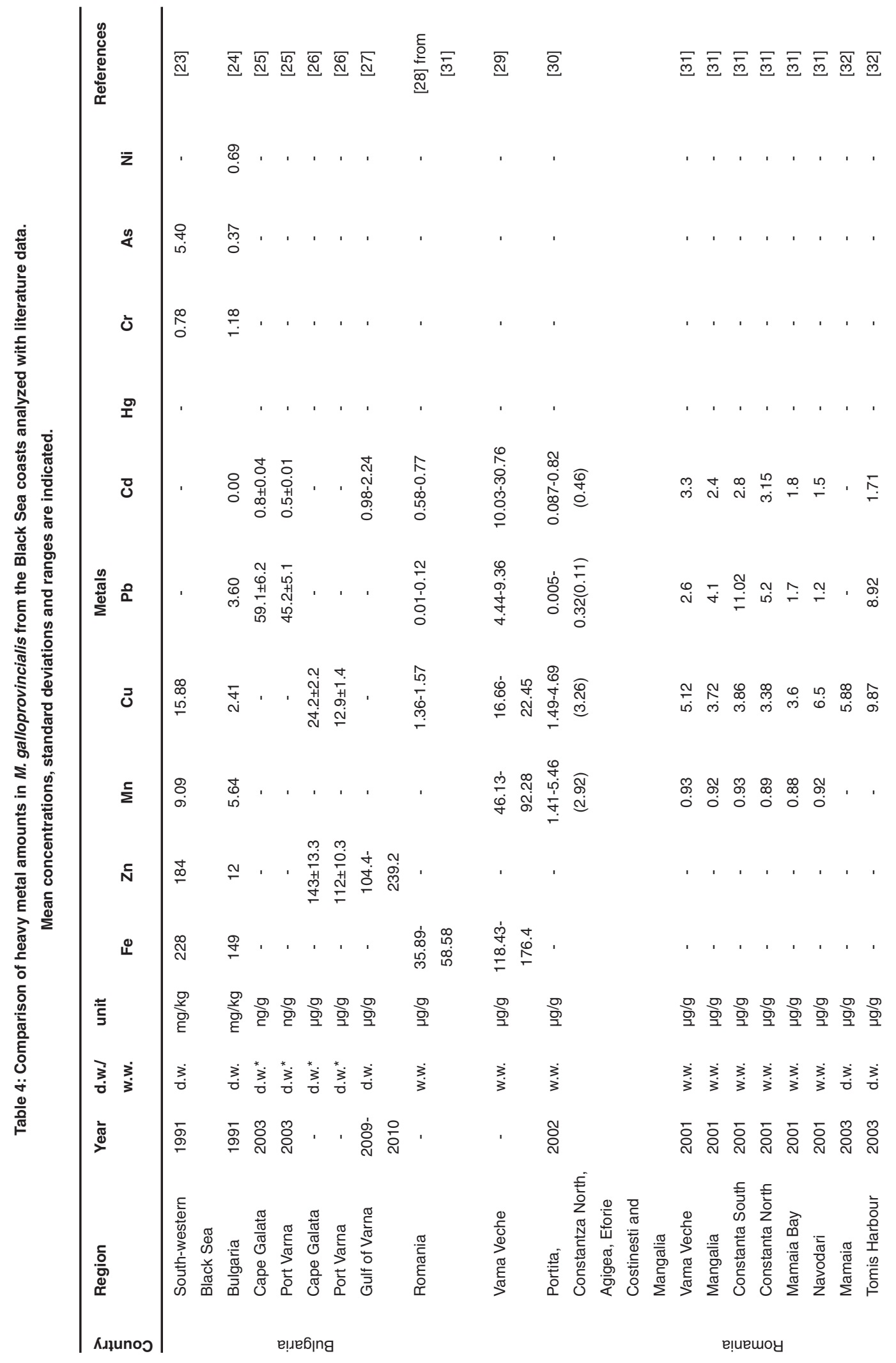


BAT et al., Curr. World Environ., Vol. 13(1) 15-31 (2018)

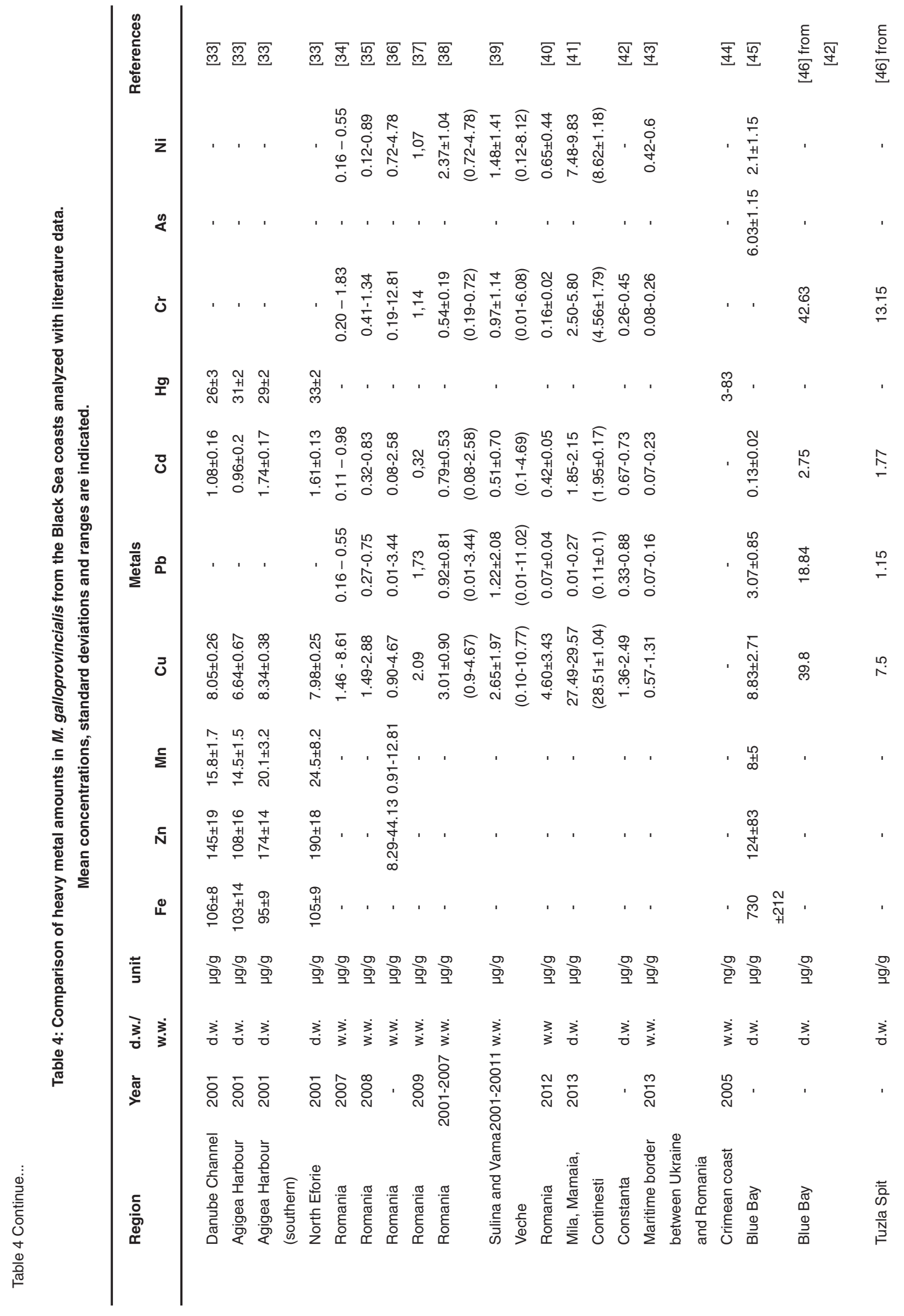




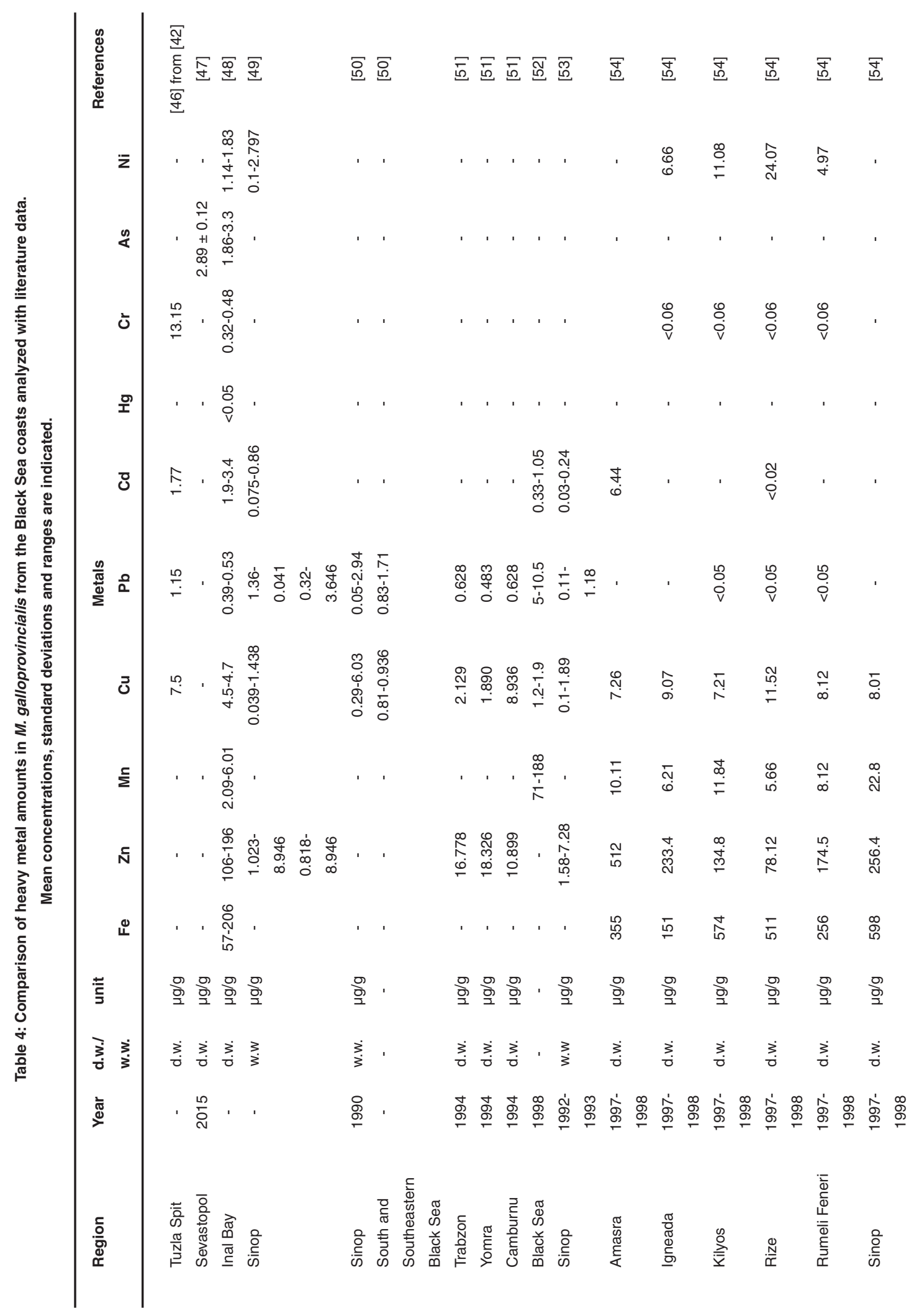




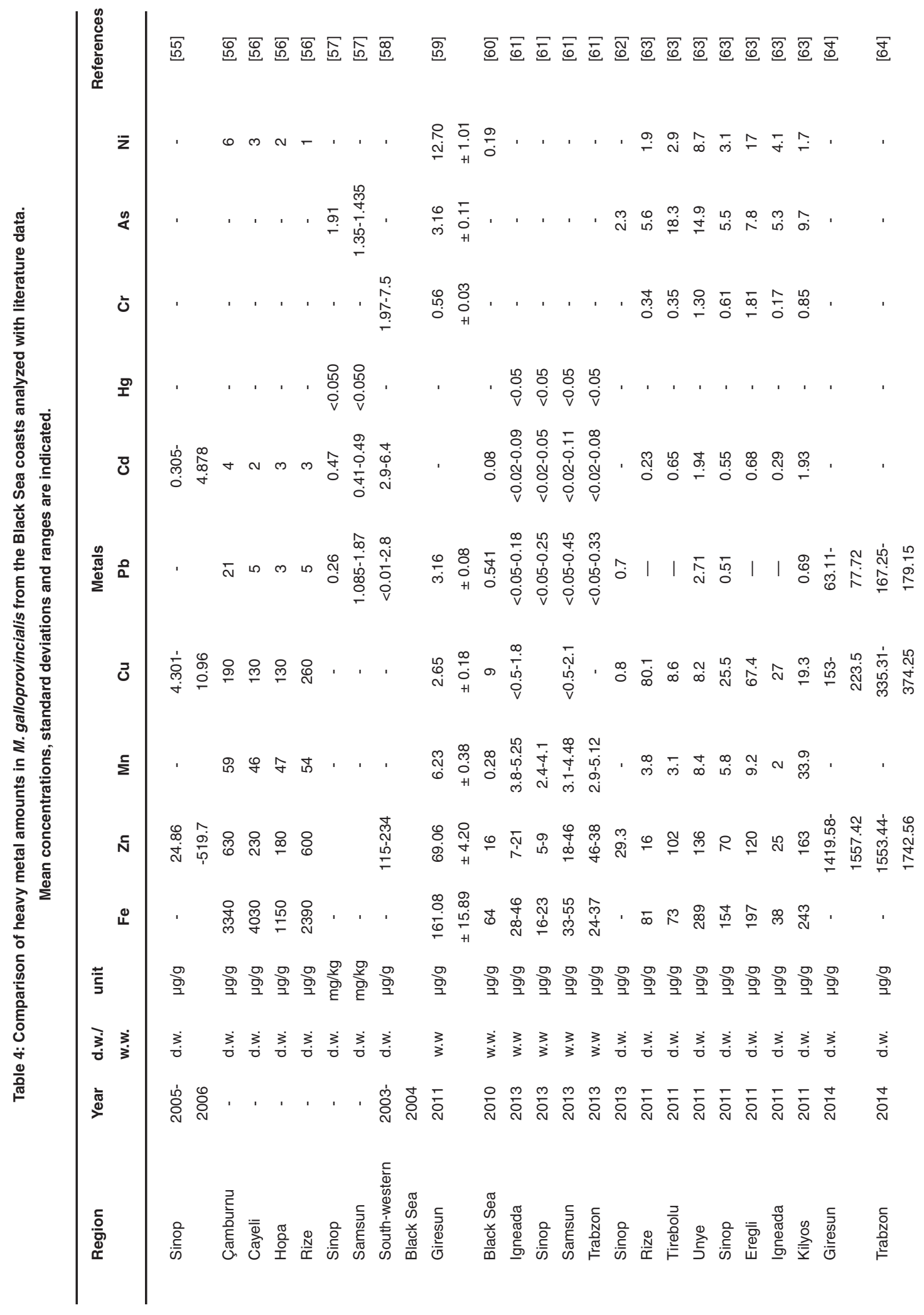


Biggest freshwater supplies of the Black Sea came from the north shore. River Danube, Dnieper and Dniester are the major rivers flowing into the Black Sea, Danube being the most pollutant one. Wastes from the European countries carried by the Danube and heavy metals carried by rivers flowing through Russia and Ukraine to the Black Sea have been cited as playing a very big role the increase of the metals in the Black Sea. Due both to natural causes and to the pollution deposited in it by large rivers carrying wastewaters from the industrialized countries, especially the heavy metals load of the Black Sea is significantly high ${ }^{14}$. In general, the average heavy metal amounts in the Black Sea mussels are below the acceptable values, but in some studies the maximum values are well above this value.

In Turkish coasts of the Black Sea, the highest values of $\mathrm{Fe}$ in Rize, $\mathrm{Zn}$ and $\mathrm{Pb}$ in Trabzon, As and $\mathrm{Ni}$ in Giresun and $\mathrm{Cu}$ in Artvin were found. The order of the metal values obtained in all studies conducted on the Turkish coast of the Black Sea are listed as $\mathrm{Fe}>\mathrm{Zn}>\mathrm{Cu}>\mathrm{Mn}>\mathrm{Pb}>\mathrm{Ni}>\mathrm{As}>\mathrm{Cr}>\mathrm{Cd}>\mathrm{Hg}$. The highest values of $\mathrm{Zn}, \mathrm{Cu}$ and $\mathrm{Pb}$ in in mussels from the Turkish Black Sea were determined by Baltas et al. ${ }^{64}$ found on the shores of Giresun, Trabzon, Artvin and Rize. The values are higher than Turkish Food Codex, the Commission Regulation and MAFF. As regards these exceed the permissible limits; yet, these organisms should not be used as food.

According to the Environment Foundation of Turkey ${ }^{14}$ environmental profile of Turkey was indicated the two main causes of metal contamination in the Black Sea are industrialization and urbanization. There has been increased population density in the coastal cities giving rise to more pollution. The rapid urbanization that has been taking place in coastal area is one of the most significant causes of the Black Sea pollution. Among the developments affecting coastal pollution in the cities, many other factors play major roles. Some of these include domestic wastes, incorrect urbanization, fishing activities, an increase in the number of tourists and inadequate disposal of wastes. Highway traffic in particular is known to cause coastal damage. Areas significantly affected by industrial pollution in the Turkish Black Sea coasts are the Istanbul, Izmit, Adapazarı, Samsun, Murgul, Karadeniz Ereglisi, Karabük and Bartin. Pollution in the Black Sea region is caused 
Table 5: Hazard analysis for the minimum and maximum amounts of elements in $M$. galloprovincialis (adopted from Stankovic et al., ${ }^{9}$ )

\begin{tabular}{|c|c|c|c|c|c|c|c|c|}
\hline Metal & Country & $\begin{array}{l}\text { Range } \\
(\mu g / g-w . w .)\end{array}$ & $\begin{array}{l}\text { RSC } \\
(g / p / d)\end{array}$ & $\begin{array}{l}\text { PTDI } \\
(\mu \mathrm{g} / \mathrm{g} / \mathrm{p} / \mathrm{d})\end{array}$ & $\begin{array}{l}\text { LOC } \\
(\mu g / g)\end{array}$ & $\begin{array}{l}\text { CLOC } \\
\text { (g/p/d) }\end{array}$ & $R Q_{\text {bes }}$ & $R Q_{\text {wes }}$ \\
\hline & Turkey & $0.00-0.89$ & 1.01 & & 69.31 & 78.65 & 0.0000 & 0.0128 \\
\hline & Bulgaria & $0.00-0.31$ & 0.8 & & 87.50 & 225.81 & 0.0000 & 0.0035 \\
\hline \multirow[t]{5}{*}{$\mathrm{Cd}$} & Romania & $0.09-30.76$ & 0.18 & 70 & 388.89 & 2.28 & 0.0002 & 0.0791 \\
\hline & Ukraine & $0.07-0.23$ & 3.51 & & 19.94 & 304.35 & 0.0035 & 0.0115 \\
\hline & Russia & $0.018-0.47$ & 1.51 & & 46.36 & 148.94 & 0.0004 & 0.0101 \\
\hline & Turkey & $0.00-24.88$ & 1.01 & & 247.52 & 10.05 & 0.0000 & 0.1005 \\
\hline & Bulgaria & 0.045-0.059 & 0.8 & & 312.50 & 4237.29 & 0.0001 & 0.0002 \\
\hline \multirow[t]{5}{*}{$\mathrm{Pb}$} & Romania & $0.001-11.02$ & 0.18 & 250 & 1388.89 & 22.69 & 0.0000 & 0.0079 \\
\hline & Ukraine & $0.07-0.16$ & 3.51 & & 71.23 & 1562.50 & 0.0010 & 0.0022 \\
\hline & Russia & $0.05-2.62$ & 1.51 & & 165.56 & 95.42 & 0.0003 & 0.0158 \\
\hline & Turkey & $0.00-0.05$ & 1.01 & & 39.60 & 816.33 & 0.0000 & 0.0012 \\
\hline & Bulgaria & - & 0.8 & & 50.00 & - & - & - \\
\hline \multirow[t]{5}{*}{$\mathrm{Hg}$} & Romania & $3.61-4.58$ & 0.18 & 40 & 222.22 & 8.73 & 0.0162 & 0.0206 \\
\hline & Ukraine & - & 3.51 & & 11.40 & - & - & - \\
\hline & Russia & $0.003-0.083$ & 1.51 & & 26.49 & 481.93 & 0.0001 & 0.0031 \\
\hline & Turkey & $5.28-559.72$ & 1.01 & & 5544.55 & 10.01 & 0.0010 & 0.1009 \\
\hline & Bulgaria & $20.69-31.66$ & 0.8 & & 7000.00 & 176.88 & 0.0030 & 0.0045 \\
\hline \multirow[t]{5}{*}{$\mathrm{Fe}$} & Romania & $13.19-176.4$ & 0.18 & 5600 & 31111.11 & 31.75 & 0.0004 & 0.0057 \\
\hline & Ukraine & - & 3.51 & & 1595.44 & - & - & - \\
\hline & Russia & $7.92-101.38$ & 1.51 & & 3708.61 & 55.24 & 0.0021 & 0.0273 \\
\hline & Turkey & $0.818-242.02$ & 1.01 & & 6930.69 & 28.92 & 0.0001 & 0.0349 \\
\hline & Bulgaria & $1.66-32.22$ & 0.8 & & 8750.00 & 217.26 & 0.0002 & 0.0037 \\
\hline \multirow[t]{5}{*}{$\mathrm{Zn}$} & Romania & 8.29-44.13 & 0.18 & 7000 & 38888.89 & 158.62 & 0.0002 & 0.0011 \\
\hline & Ukraine & - & 3.51 & & 1994.30 & - & - & - \\
\hline & Russia & 14.72-196 & 1.51 & & 4635.76 & 35.71 & 0.0032 & 0.0423 \\
\hline & Turkey & $0.28-26.11$ & 1.01 & & $\begin{array}{l}1980.2- \\
4950.5\end{array}$ & $\begin{array}{l}76.59- \\
191.49\end{array}$ & $\begin{array}{l}0.0001- \\
0.0001\end{array}$ & $\begin{array}{l}0.0132- \\
0.0053\end{array}$ \\
\hline & Bulgaria & $0.78-1.26$ & 0.8 & & $\begin{array}{l}2500- \\
6250\end{array}$ & $\begin{array}{l}1587.30- \\
3968.25\end{array}$ & $\begin{array}{l}0.0003- \\
0.0001\end{array}$ & $\begin{array}{l}0.0005- \\
0.0002\end{array}$ \\
\hline \multirow[t]{5}{*}{$\mathrm{Mn}$} & Romania & $0.88-92.28$ & 0.18 & $\begin{array}{l}2000- \\
5000\end{array}$ & $\begin{array}{l}11111.11- \\
27777.78\end{array}$ & $\begin{array}{l}21.67- \\
54.18\end{array}$ & $\begin{array}{l}0.0001- \\
0.000\end{array}$ & $\begin{array}{l}0.0083- \\
0.0033\end{array}$ \\
\hline & Ukraine & - & 3.51 & & $\begin{array}{l}569.8- \\
1424.5\end{array}$ & - & - & - \\
\hline & Russia & $0.29-1.11$ & 1.51 & & $\begin{array}{l}1324.50- \\
3311.26\end{array}$ & $\begin{array}{l}1801.8- \\
4504.51\end{array}$ & $\begin{array}{l}0.0001- \\
0.00009\end{array}$ & $\begin{array}{l}0.0008- \\
0.0033\end{array}$ \\
\hline & Turkey & 0.04-90.85 & 1.01 & & 3465.35 & 38.53 & 0.00001 & 0.0262 \\
\hline & Bulgaria & $0.33-3.36$ & 0.8 & & 4375.00 & 1041.67 & 0.00008 & 0.0008 \\
\hline \multirow[t]{3}{*}{$\mathrm{Cu}$} & Romania & $0.19-22.45$ & 0.18 & 3500 & 19444.44 & 155.90 & 0.00001 & 0.0012 \\
\hline & Ukraine & $0.57-1.31$ & 3.51 & & 997.15 & 2671.76 & 0.00057 & 0.0013 \\
\hline & Russia & $0.625-5.53$ & 1.51 & & 2317.88 & 632.91 & 0.00027 & 0.0024 \\
\hline
\end{tabular}

RSC = Rate of Shellfish Consumption (g/person/day) ${ }^{68}$

RSC-Turkey $(1.01 \mathrm{~g} / \mathrm{p} / \mathrm{d})$, Bulgaria $(0.8 \mathrm{~g} / \mathrm{p} / \mathrm{d})$, Romania $(0.18 \mathrm{~g} / \mathrm{p} / \mathrm{d})$, Ukraine $(3.51 \mathrm{~g} / \mathrm{p} / \mathrm{d})$, Russia (1.51 $\mathrm{g} / \mathrm{p} / \mathrm{d})]$

LOC = Level of concern (in $\mu \mathrm{g} / \mathrm{g})$ (PTDI / RSC )

CLOC = Consumption Level of Concern (in g/person/day) ( RSC x LOC / MAX )

$R Q_{\text {bes }}=$ Risk Quotient for the best case scenario ( $X$ min / LOC )

$R Q_{\text {wes }}=$ Risk Quotient for the worst case scenario ( $X$ max / LOC )

$\mathrm{PTDI}=$ Permissible Tolerable Daily Intake (in $\mu \mathrm{g} /$ person/day) PTDI= $(\mathrm{PTWl} \times 70 \mathrm{~kg}) /(7$ days $)$

PTDI ( $\mu$ g/person/day) - Cd (70), Pb (250), Hg (40), Fe (5600), Zn (7000), Mn (2000-5000), Cu (3500) 
by the fertilizer, iron and steel, paper and cellulose, and cement industries. The fertilizer industry is located in Samsun, the iron and steel industry at Eregli and Karabük, the paper and cellulose industry at Çaycuma and the cement industry in Bartın, Trabzon and Ünye. The mining operations at Murgul and Zonguldak are also responsible for pollution as is urbanization, which has contributed to pollutants in Trabzon especially. Industrial pollution dominates the household heating in Samsun, particularly due to nitrogen based fertilizers and copper factories, $15 \mathrm{~km}$ east of the city. The major sources of pollution of the Sakarya River are Seydi Creek, Ankara Creek, Çark Stream, which takes up the used waters of Adapazarı and also carries the runoff of Lake Sapanca to the Sakarya and the industrial enterprises in the Adapazarı area. These creeks and streams take up the wastewater of many cities and join the Sakarya River ${ }^{14}$.

The highest $\mathrm{Zn}$ value was $1742.56 \mu \mathrm{g} / \mathrm{g}$ dry wt. $^{64}$, followed by $630 \mu \mathrm{g} / \mathrm{g}$ dry wt. ${ }^{56}$, in the coast of Trabzon in the Turkish Black Sea. However the highest $\mathrm{Cu}$ was $654.13 \mu \mathrm{g} / \mathrm{g}$ in Artvin $\mu \mathrm{g} / \mathrm{g}$ dry wt. ${ }^{64}$ followed by $260 \mu \mathrm{g} / \mathrm{g}$ in Trabzon $\mu \mathrm{g} / \mathrm{g}$ dry wt. ${ }^{56}$. The highest $\mathrm{Pb}$ value was $179.15 \mu \mathrm{g} / \mathrm{g}$ dry wt. (approximately $24.88 \mu \mathrm{g} / \mathrm{g}$ wet wt. $)^{64}$, followed by $3.16 \pm 0.0824 .88$ $\mu \mathrm{g} / \mathrm{g}$ wet wt. ${ }^{59}$ in the coast of Trabzon.

Comparisons of heavy metal studies on the coasts of the Black Sea are given in in the risk assessment (see Table 4). For this aim if heavy metal levels in M. galloprovincialis are given as dry wt., they were transformed to wet wt. dividing by 7.2 as factor and all outcomes are given on a wet weight basis as $\mu \mathrm{g} / \mathrm{g}$ wet wt. ${ }^{67}$.

Health risk from metals intake via diet may be estimated using a Risk Quotient (RQ) as the ratio of the calculated metal dose and the reference dose (see Table 5).

Rf. D values were developed by US EPA and Agency for Toxic Substances and Disease Registry (ATSDR) for seafood consumption as estimates of daily exposures to a contaminant that are probably without a noticeable risk of injurious effects to the general population during a lifespan of exposure.

It is concluded that estimated $\mathrm{RQ}$ of $\mathrm{Cd}, \mathrm{Pb}, \mathrm{Hg}$, $\mathrm{Fe}, \mathrm{Zn}, \mathrm{Mn}$ and $\mathrm{Cu}$ in the M. galloprovincialis do not hazard any apparent threat to human, where the total hazard index $(\mathrm{THI})=0.521$ were below the value of 1 .

\section{Conclusions}

The mean concentrations of total heavy metals in mussels from Sinop coasts were lower than those in other cities in the Turkish Black Sea coasts. Samsun shows the higher concentrations of $\mathrm{Fe}, \mathrm{Cu}, \mathrm{Cd}$ and $\mathrm{Hg}$ whereas $\mathrm{Zn}$ and $\mathrm{Pb}$ levels were higher in Trabzon and $\mathrm{Mn}$ was maximum value in Igneada. However these amounts were quite down the limit founded by EU legislation for non-essential heavy metals $\mathrm{Hg}, \mathrm{Cd}$ and $\mathrm{Pb}$. Thus, the mussels' consumption in the Black Sea countries diet doesn't pose a risk for population in terms of these studied heavy metals. Considering public health in adult persons with respect to the investigated heavy metals, the estimated daily intakes (EDIs) did not exceed the tolerable intakes. There was no health risk since the target hazard quotients (THQs) were far below critical value 1.Therefore, consuming M. galloprovincialis does not involve any danger to the public health in terms of studied heavy metals.

Overall conclusion is that the mussels M. galloprovincialis are appropriate bio-monitors to state change in metal contamination in whole the Black Sea coasts.

\section{Conflict of interest}

We declare that we have no conflict of interest.

\section{Acknowledgements}

The researchers wish to acknowledge the Department of Hydrobiology, Fisheries Faculty, University of Sinop for providing laboratory facilities during the study. 


\section{References}

1. Official Journal of the European Union. Directives Directive 2008/56/EC of the European Parliament and of the Council of 17 June 2008 Establishing a Framework for Community Action in the Field of Marine Environmental Policy. Marine Strategy Framework Directive, L 164: 19-40 (2008).

2. Official Journal of the European Communities. Directive 2000/60/EC of the European Parliament and of the Council of 23 October 2000. Establishing a Framework for Community Action in the Field of Water Policy, L 327: 1-72 (2000).

3. Zaitsev, Yu, and V. Mamaev. "Marine biological diversity in the Black Sea." A study of change and decline United Nations Publications New York 208 (1997).

4. Bat, L., Gokkurt, O., Sezgin, M., Ustün, F. and Sahin, F. Evaluation of the Black Sea Land Based Sources of Pollution the Coastal Region of Turkey. The Open Marine Biology Journal, 3: 112-124 (2009).

5. Phillips, D.J.H. and Rainbow, P.S. Biomonitoring of Trace Aquatic Contaminants. Environmeantal Management Series, Chapman \& Hall, London (1994).

6. Phillips, D.J.H. Quantitative Aquatic Biological Indicators Their Use to Monitor Trace Metal and Organochlorine Pollution. Applied Science Publishers Ltd., London (1980).

7. McCurry, J. Japan Remembers Minamata. Lancet,367: 99-100 (2006).

8. The Earth Report 3. An A-Z Guide to Environmental Issues. (General Eds.) Goldsmith E, Hildyard N: London (1992).

9. Stankovic, S., Jovic, M., Stankovic, A. R. And Katsikas, L. Heavy Metals in Seafood Mussels. Risks for Human Health. In Environmental chemistry for a sustainable world (pp. 311373). Springer Netherlands (2012).

10. FAO (Food and Agriculture Organization of the United Nations). Fishery Statistical Collections, Global Production Statistics 1950-2015. Online at: http://www.fao.org/ fishery/statistics/global-production/query/en

11. Commission Regulation (EC). Setting
Maximum Levels for Certain Contaminants in Foodstuffs. No 1881 (2006).

12. Official Gazette of Republic of Turkey. Notifications about Determination of the Maximum Levels for Certain Contaminants in Food stuffs of Turkish Food Codex (inTurkish). (Notification No: 2002/63), Issue: 24885 (2002).

13. Official Gazette of Republic of Turkey. Notifications Changes to the Maximum Levels for Certain Contaminants in Foodstuffs (in Turkish). (Notification No: 2009/22), Issue: 27143 (2009).

14. Environment Foundation of Turkey. Environmental profile of Turkey. Önder Matbaa, Ankara, ISBN 975-7250-16-3, 280 p. (1995).

15. Council of Europe. Council of Europe's Policy Statements Concerning Materials and Articles Intended to Come into Contact with Foodstuffs. Policy Statement Concerning Materials and Alloys. Technical Document. Guidelines on metals and alloys used as food contact materials, 67 pp., Strasbourg (2001).

16. MAFF (The Ministry of Agriculture, Forestry and Fisheries). Monitoring and Surveillance of Non-Radioactive Contaminants in the Aquatic Environment and Activities Regulating the Disposal Wastes at Sea. Directorate of Fisheries research, Lowestoft, Aquatic Environment Monitoring Report, No.44 (1995).

17. FAO (Food and Agriculture Organization of the United Nations). The Food Consumption Refers to the Amount of Food Available for Human Consumption as Estimated by the FAO. Food Balance Sheets (2010).

18. Bat, L. Heavy Metal Pollution in the Black Sea. In: Düzgünes E, Öztürk B, Zengin M. (Eds.). Turkish Fisheries in the Black Sea, Published by Turkish Marine Research Foundation (TUDAV), Publication number: Istanbul, Turkey, 40: 71-107 (2014).

19. Phillips, D.J.H. The Use of Biological Indicator Organisms to Monitor Trace Metal Pollution 
in Marine and Estuarine Environments. A Review. Environ. Pollut., 13: 281-317 (1977).

20. Phillips, D.J.H. The Common Mussel Mytilus edulis as an Indicator of Pollution by Zinc, Cadmium, Lead and Copper. I. Effects of Environmental Variables on Uptake of Metals. Mar. Biol., 38: 59- 69 (1976).

21. Phillips, D.J.H. The Common Mussel Mytilus edulis as an Indicator of Pollution by Zinc, Cadmium, Lead and Copper. II. Relationship of Metals in the Mussel to those Discharged by Industry. Mar. Biol., 38: 71-80 (1976).

22. Phillips, D.J.H. and Rainbow, P.S. Barnacles and Mussels as Biomonitors of Trace Elements: A Comparative Study. Mar. Ecol. Prog. Ser., 49: 83-93 (1988).

23. Andreev, G. and Simeonov, V. Interphase Distribution and Accumulation of Elements in the Marine Environment of the Black Sea. Toxicological \& Environmental Chemistry, 36(1-2): 99-104 (1992).

24. Andreev, G., Simeonov, V. and Stoikov, S. Occurrence and Distribution of Heavy Metals in Benthic Organisms from the Black Sea. Toxicological \& Environmental Chemistry, 45(3-4): 167-171 (1994).

25. Gorinstein, S., Jung, S. T., Moncheva, S., Arancibia-Avila, P., Park, Y. S., Kang, S. G. ... and Namiesnik, J. Partial Characterization of Proteins from Mussel Mytilus galloprovincialis as a Biomarker of Contamination. Archives of environmental contamination and toxicology, 49(4): 504-510 (2005).

26. Gorinstein, S., Moncheva, S., Toledo, F., Arancibia-Avila, P., Trakhtenberg, S., Gorinstein, A.... and Namiesnik, J. Relationship between Seawater Pollution and Qualitative Changes in the Extracted Proteins from Mussels Mytilus galloprovincialis. Science of the total environment, 364(1): 251-259 (2006).

27. Simeonova, P., Simeonov, D., Spassov, L. and Simeonov, V. Determination and Statistical Interpretation of Toxic Metals Content in Mollusks and Snails from Black Sea. Bulgarian Journal of Chemistry, 2(3),:105-114 (2013).

28. Serbanescu, O., Munteanu, G., Pecheanu, I. and Mihnea I. Mytilus galloprovincialis de la Cote Roumaine de la Mer Noire, Factor de Concentration en Metaux Lourds. Ves Journees Etud. Pollution, Cagliari, CIESM, 1980, 573-576 (1980).

29. Bologa A.S., Apas M., Cociasu A., Cuingioglu E., Patrascu V., Piescu I. and Popa L. Present Level of Contaminants in Romanian Black Sea Sector Marine pollution. Proceeding of a symposium held in Monaco, 5-9 Oct. 1998. IAEA SM-354/26: 58-63 (1998).

30. Oros, A., Mihnea, R. and Pecheanu, I. Considerations Regarding Trace Metal Presence in Marine Ecosystem Components along the Romanian Black Sea Coastal Zone. Cercetari Marine, 34:197-208 (2002).

31. Oros, A., Pecheanu, I. and Mihnea, R. Bioaccumulation in Mytilus galloprovincialis along the Romanian Black Sea Coastal Area. Journal of Environmental Protection and Ecology, 4(4): 850-856 (2003).

32. Stanciu, G., Mititelu, M. and Gutaga, S. Pesticides and Heavy Metals Determination in Marine Organisms from Black Sea. Chemical Bulletin, 50(64): 1-2 (2005).

33. Roméo, M., Frasila, C., Gnassia-Barelli, M., Damiens, G., Micu, D. and Mustata, G. Biomonitoring of Trace Metals in the Black Sea (Romania) Using Mussels Mytilus galloprovincialis. Water research, 39(4): 596604 (2005).

34. INCDM. State of the Marine and Coastal Environment Report, National Institute of Marine Research and Development, (in Romanian), (2008). Online at: http://www. rmri.ro/RMRI/RaportStareaMediului/Rapo rtStareaMediului_2008-1.pdf (2008).

35. INCDM. State of the Marine and Coastal Environment Report, National Institute of Marine Research and Development, (in Romanian), On line at: http://www. rmri.ro/RMRI/RaportStareaMediului/Rapo rtStareaMediului_2009-1.pdf (2009).

36. Oros, A. The Contributions to Acknowledging the Consequences of the Heavy Metals Pollution on the Coastal Marine Ecosystems from the Romanian Littoral of the Black Sea. University "Ovidius" of Constanta, Romania, PhD Thesis (2009).

37. INCDM, State of the Marine and Coastal Environment Report, National Institute of 
Marine Research and Development, (in Romanian), Online at: http://www.rmri. ro/RMRI/RaportStareaMediului/Rapo rtStareaMediului_2010.pdf (2010).

38. Oros, A. and Gomoiu, M. T. Comparative Data on the Accumulation of Five Heavy Metals (Cadmium, Chromium, Copper, Nickel, Lead) in Some Marine Species (Molluscs, Fish) from the Romanian Sector of the Black Sea. Recherches Marines, 39: 89-108 (2010).

39. Oros, A. and Gomoiu, M. T. A. Review of Metal Bioaccumulation Levels in the Romanian Black Sea Biota During the Last Decade-A Requirement for Implementing Marine Strategy Framework Directive (Descriptors 8 and 9). J Environ Prot Ecol, 13(3): 1730 (2012).

40. Jitar, O., Teodosiu, C., Oros, A., Plavan, G., \& Nicoara, M. Bioaccumulation of Heavy Metals in Marine Organisms from the Romanian Sector of the Black Sea. New biotechnology, 32(3): 369-378(2015).

41. Rosioru, D.M., Oros, A.and Lazar, L.Assessment of the Heavy Metals Contamination in Bivalve Mytilus galloprovincialis Using Accumulation Factors. Journal of Environmental Protection and Ecology, 17(3): 874-884 (2016).

42. Catherine, T., Vanessa, M., Evangelia, S., Valentina, C., Andreja, R., Rana, A. A. ... and Ioannis, H. Biochemical Biomarker Responses to Pollution in Selected Sentinel Organisms Across the Eastern Mediterranean and the Black Sea. Environmental Science and Pollution Research, 23(2): 1789-1804 (2016).

43. Strungaru, S. A., Nicoara, M., Teodosiu, C., Micu, D., \& Plavan, G. Toxic Metals Biomonitoring Based on Prey-Predator Interactions and Environmental Forensics Techniques: A Study at the RomanianUkraine Cross Border of the Black Sea. Marine Pollution Bulletin, 124(1): 321-330 (2017)

44. Egorov, V. N., Lazorenko, G. E., Mirzoyeva, N. Y., Stokozov, N. A., Kostova, S. K., Malakhova, L. V., ... and Plotitsyna, O. V. Content of 137 Cs, $40 \mathrm{~K}, 90 \mathrm{Sr}, 210$ Po Radionuclides and Some Chemical Pollutants in the Black Sea Mussels, Mytilus galloprovincialis Lam. Marine Ecological Journal, 5(3): 70-78
(2006).

45. Demina L.L. and Budko D.M. Trace Metals in Carbonate Biomineralization By The Example of Bivalvia Mytilus spp. from the Black Sea. (in Russian) Geologo-Mineralogical SciencesFundamental Research 11-10 (2014).

46. Ananoym. Database of the State Oceanographic Institute. Online at: http:// esimo.oceanography.ru/esp2/index/index/ esp_id/10/section_id/8/menu_id/4426

47. Ryabushko, V.I., Kozintsev, A.F. and Toichkin, A.M. Concentration of Arsenic in the Tissues of Cultivated Mussel Mytilus galloprovincialis Lam., Water and Bottom Sediments (Crimea, Black Sea) (in Russian). Marine Biological Journal,2: 3 (2017).

48. Temerdashev, Z. A., Eletskii, I. I., Kaunova, A. A., \& Korpakova, I. G. Determination of Heavy Metals in Mytilus galloprovincialis Lamarck mussels using the ICP-AES method. (in Russian). Analytics and control, 21(2): 116124 (2017).

49. Ozturk, M. A. Study On the Two Invertebrata and Two Algae Species for the Their Heavy Metal Build Up on Their Respective Levels Those Tend to Live in Sinop Province's Inner and Outer Harbors or Coves. (in Turkish). Ondokuz Mayıs University, Turkey PhD Thesis, pp:85 (1991).

50. Unsal, M., Dogan, M., Atac, Ü., Yemencioglu, S., Akdogan, S., Kayikci, Y. and Aktas, M. Determination of Heavy Metals in the Mrine Organisms of Economical Importance in the Central and Eastern Black Sea. Tarım ve Köyisleri Bakanligi Trabzon Su Ürünleri Arastırma Enstitüsü. Project No: DEBAG18/G: pp: 52 (in Turkish) (1992).

51. Boran, M. and Karacam, H. Trace Element Levels of Mussels (Mytilus galloprovincialis Lamarck, 1819 ) in Trabzon Coastline.Ege Journal of Fisheries and Aquatic Sciences (EgeJFAS), 14 (3-4): 336-344 (in Turkish) (1997).

52. Unsal, M., Cagatay, N., Bekiroglu, Y., Kıratlı, N., Alemdag, N. and Sari, E. Trace Element Pollution in the Black Sea. Tarim ve Köy Isleri Bakanligi Trabzon Su Ürünleri Arastirma Enstitüsü, Project No. YDEBÇAG-456/G457/G, 70pp. Mersin/Turkey (in Turkish) 
(1998).

53. Bat, L., Gundogdu, A., Ozturk, M. and Ozturk, M. Copper, Zinc, Lead and Cadmium Concentrations in the Mediterranean Mussel Mytilus galloprovincialis Lamarck, 1819 from the Sinop coasts of the Black Sea. Tr. J. of Zoology, 23: 321-6 (1999).

54. Topcuoglu, S., Kırbasoglu, Ç. And Gungor, N. Heavy Metals in Organisms and Sediment from Turkish Coast of the Black Sea, 19971998. Environment International, 27: 521-6 (2002).

55. Turk Culha, S. Bat, L., Culha, M., Efendioglu, A., Andac, M. and Bati, B. Heavy Metals Levels in Some Fishes and Molluscs from Sinop Peninsula of the Southern Black Sea, Turkey. Rapp. Comm. Int. Mer Medit. 38:323 (2007).

56. Cevik, U., Damla, N., Kobya, A. I., Bulut, V. N., Duran, C., Dalgic G. and Bozaci, R. Assessment of Metal Element Concentrations in Mussel (Mytilus galloprovincialis) in Eastern Black Sea, Turkey. Journal of Hazardous Materials 160(2-3): 396-401 (2008).

57. Das, Y.K., Aksoy, A., Baskaya, R., Duyar, H.A., Güvenc, D. and Boz, V. Heavy Metal Levels of Some Marine Organisms Collectes in Samsun and Sinop Coasts of Black Sea, in Turkey. Journal of Animal and Veterinary Advances 8 (3): 496-99 (2009).

58. Balkıs, N., Aksu, A., Hiçsönmez, H. Metal Levels in Biota from the Southern Black Sea, Turkey. J. Black Sea/Mediterranean Environment, 18(2): 134-143 (2012).

59. Süer, N. The Levels of Heavy Metals in (Mytilus galloprovincialis Lamarck, 1819) the Mediterranean Mussel; Examples of Giresun Coasts (in Turkish). University of Giresun Graduate School of Natural and Applied Sciences Deparment of Biology, Master Thesis. 75 pp. (2013).

60. Bat, L., Arıcı, E., Sezgin, M. and Sahin, F. Heavy Metals in Edible Tissues of Benthic Organisms from Samsun Coasts, South Black Sea, Turkey and Their Potential Risk to Human Health. Journal of Food and Health Science, 2(2): 57-66 (2016).

61. Arıcı, E. and Bat, L. Heavy Metal
Levels in Mediterranean Mussel Mytilus galloprovincialis from the Turkish Black Sea Coast as Biomonitor and Potential Risk of Human Health. $2^{\text {nd }}$ International Conference on One Medicine One Secience, April 24-27, 2016.University of Minnesota, Minneapolis, USA (2016).

62. Bat, L.and Öztekin, H.C. Heavy Metals in Mytilus galloprovincialis, Rapana venosa and Eriphia verrucosa from the Black Sea Coasts of Turkey as Bioindicators of Pollution. Walailak J. Sci. Technol. 13 (9): 715-728 (2016).

63. Belivermis, M., Kılıç, Ö. and Çotuk, Y. Assessment of Metal Concentrations in Indigenous and Caged Mussels (Mytilus galloprovincialis) on Entire Turkish Coastline. Chemosphere, 144: 1980-1987 (2016).

64. Baltas, H., Sirin, M., Dalgic, G., Bayrak, E. Y. and Akdeniz, A. Assessment of Metal Concentrations $(\mathrm{Cu}, \mathrm{Zn}$, and $\mathrm{Pb})$ in Seawater, Sediment and Biota Samples in the Coastal Area of Eastern Black Sea, Turkey. Marine Pollution Bulletin, 122(1-2): 475-482 (2017).

65. Çulha, S. T., Çulha, M., Karayücel, i., Çelik, M. Y. and Isler, Y. Heavy Metals in Mytilus galloprovincialis, Suspended Particulate Matter and Sediment from Offshore Submerged Longline System, Black Sea. International Journal of Environmental Science and Technology, 14(2): 385-396 (2017).

66. Bat L. Arıcı E., Öztekin A., Yardım O., and Üstün F., Use of the Mediterranean mussel Mytilus galloprovincialis Lamarck, 1819 from Sinop coasts of the Black Sea as biomonitor, International Journal of Marine Science, 8(5): 44-47 (2018). doi:10.5376/ ijms.2018.08.0005.

67. Ricciardi, A. and Bourget, E. Weight-to-Weight Conversion Factors for Marine Benthic Macroinvertebrates. Marine Ecology Progress Series, 163: 245-251 (1998).

68. FAO (Food and Agriculture Organization of the United Nations). Fishery Statistical Collections, Consumption of Fish and Fishery Products. Online at: http://www.fao.org/ fishery/statistics/global-consumption/en 